\title{
Levodopa-carbidopa-entacapone overdose presenting as altered mental status, xanthoderma, and yellowish sclera
}

\author{
SUN HWA LEE, SEONG JONG YUN², SEOKYONG RYU ${ }^{1}$, SEUNG WOON CHOI', HYE \\ JIN KIM ${ }^{1}$, TAE KYUNG KANG ${ }^{1}$, SUNG CHAN OH ${ }^{1}$, SUK JIN CHO \\ 1 Department of Emergency Medicine, Sanggye Paik Hospital, Inje University College of Medicine, Seoul, Republic of Korea \\ 2 Department of Radiology, Kyung Hee University Hospital at Gangdong, Kyung Hee University School of Medicine, Seoul, Republic of Korea
}

Correspondence:

Seong Jong Yun

Department of Radiology

Kyung Hee University Hospital at Gangdong

Kyung Hee University School of Medicine

892 Dongnam-ro, Gangdong-gu

Seoul, 05278, Republic of Korea

Phone: +822 440-6933

Fax: +822 440-6932

E-mail:zoomknight@naver.com

\section{ABSTRACT}

Levodopa-carbidopa-entacapone is a single combination drug consisting of levodopa (aromatic amino acid), carbidopa (dopa-decarboxylase inhibitor), and entacapone (catechol-O-methyltransferase inhibitor). The Food and Drug Administration approved levodopa-carbidopaentacapone in 2003, as treatment for idiopathic Parkinson's disease in patients experiencing signs and symptoms of wearing-off. Although various adverse drug reactions of levodopa-carbidopa-entacapone have been recorded, there has been no reported case of levodopa-carbidopa-entacapone overdose. We report the first case of signs and symptoms of an overdose of levodopa-carbidopa-entacapone (levodopa: $3000 \mathrm{mg}$; carbidopa: $750 \mathrm{mg}$; entacapone: $6000 \mathrm{mg}$ ) in a suicide attempt, presenting as altered mentality, xanthoderma, and yellowish sclera without hyperbilirubinemia.

Key words: levodopa-carbidopa-entacapone, Parkinson's disease, drug overdose, xanthoderma, yellowish sclera, toxicology

\section{INTRODUCTION}

Levodopa-carbidopa-entacapone is a triple combination drug containing levodopa, carbidopa, and entacapone. In 2003, this drug was approved by the Food and Drug Administration (FDA) and considered the main treatment option for Parkinson's

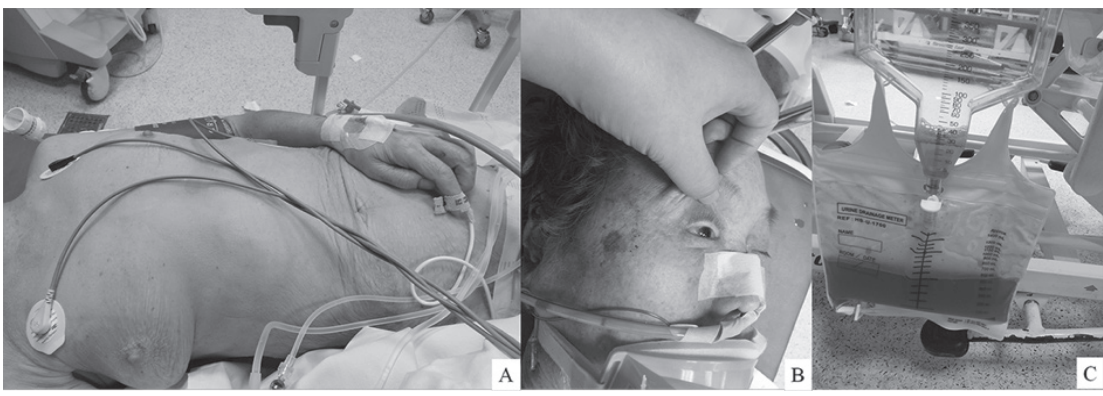

Figure 1. Photograph images of the patients' whole body (A), eye (B), and urine via Foley catheter $(C)$. These show yellowish skin color (xanthoderma) (A) and yellowish sclera (B). Urine color is somewhat dark yellow to reddish (C).

disease (PD). (1) Adverse drug reactions associated with the recommended dose of levodopa-carbidopa-entacapone have been reported to be at least $3 \%$ greater than placebo incidences, and these include dyskinesia, urine discoloration, diarrhea, nausea, hyperkinesia, vomiting and dry mouth. (2)

Concerning the overdose of this drug, a few cases of levodopa alone or levodopacarbidopa overdose have been reported. (3-6) However, there have been no reports on levodopa-carbidopa-entacapone overdose. We report the first case of a patient who ingested excess levodopa-carbidopaentacapone in an attempt to commit suicide.

\section{CASE PRESENTATION}

A 77-year-old woman presented at our emergency department, with complaint from her son of altered mental status. She had a previous medical history of $\mathrm{PD}$, for which she had received treatment for 4 years. In the morning, her son found her unconscious in the living room with 30 torn and remnants of the tablet. The last call was to her son 30 minutes before. Upon arrival, her vital signs were unstable (60/40 mmHg-110 beats/min-26 breaths/ min- $34^{\circ} \mathrm{C}$ ) Physical examination showed the patient was in a state of stupor, with dilated pupils, sluggish light reflex, xanthoderma of the whole body (figure 1A) and yellowish sclera (figure 1B). Initial resuscitation included tracheal intubation, intravenous fluid infusions, inotropic agents, gastric lavage and orally administered activated charcoal. At that point, we suspected a case of hyperbilirubinemia, related to hepatic failure due to ingestion of an unknown drug.

The laboratory findings including liver function test (total bilirubin: $0.9 \mathrm{mg} / \mathrm{dL}$; 
Table 1. Reported studies of the drug overdosage in Parkinson's disease patients with levodopa therapy

\begin{tabular}{|c|c|c|c|c|c|c|c|c|}
\hline Authors & Year & Age/Sex & Drug & $\begin{array}{l}\text { No. of } \\
\text { tables }\end{array}$ & $\begin{array}{l}\text { Total drug } \\
\text { dose }\end{array}$ & Symptoms & $\begin{array}{l}\text { Abnormal laboratory } \\
\text { finding at the time of the } \\
\text { hospital visit }\end{array}$ & $\begin{array}{l}\text { Interval between } \\
\text { drug ingestion and } \\
\text { hospital visit }\end{array}$ \\
\hline Hoehn, et al3 & 1975 & $61 / \mathrm{M}$ & $\begin{array}{l}\text { Levodopa } \\
\text { alone }\end{array}$ & $\begin{array}{l}\text { Not } \\
\text { reported }\end{array}$ & $\begin{array}{l}\text { Levodopa: } \\
\text { upto } 100 \mathrm{mg}\end{array}$ & $\begin{array}{l}\text { Altered mentality, dia- } \\
\text { phoretic.and restless, } \\
\text { constant speech, jerk } \\
\text { movement }\end{array}$ & $\begin{array}{l}\text {-Elevated serum CK, } \\
\text { LDH, creatinine, glutamic } \\
\text { oxaloacetic acid, glutarnic } \\
\text { pyruvic acid transaminase }\end{array}$ & Several hours \\
\hline Sporer4 & 1991 & $57 / \mathrm{F}$ & $\begin{array}{l}\text { Levodopa- } \\
\text { carbidopa }\end{array}$ & 15 & $\begin{array}{l}\text { Levodopa: } \\
1500 \mathrm{mg} \\
\text { Carbidopa: } \\
150 \mathrm{mg}\end{array}$ & $\begin{array}{l}\text { Altered mentality, } \\
\text { lethargy, choreiform } \\
\text { movements }\end{array}$ & $\begin{array}{l}\text { Elevated serum CK, LDH, } \\
\text { hematuria, myoglobinuria }\end{array}$ & 2 hours \\
\hline $\begin{array}{l}\text { Stuerenburg } \\
\text { et al5 }\end{array}$ & 1999 & $76 / \mathrm{M}$ & $\begin{array}{l}\text { Levodopa- } \\
\text { carbidopa }\end{array}$ & 30 & $\begin{array}{l}\text { Levodopa: } \\
6000 \mathrm{mg} \\
\text { Carbidopa: } \\
1500 \mathrm{mg}\end{array}$ & $\begin{array}{l}\text { Altered mentality, } \\
\text { anxious, depressed, } \\
\text { agitated, subeuphoric, } \\
\text { visual hallucinations }\end{array}$ & Not reported & About $1 \sim 2$ hours \\
\hline Delmas, et al6 & 2008 & $55 / \mathrm{M}$ & $\begin{array}{l}\text { Levodopa- } \\
\text { carbidopa }\end{array}$ & 89 & $\begin{array}{l}\text { Levodopa: } \\
17800 \mathrm{mg} \\
\text { Carbidopa: } \\
4450 \mathrm{mg}\end{array}$ & $\begin{array}{l}\text { Psychomotor agita- } \\
\text { tion, delirium, jovial- } \\
\text { ity, visual hallucina- } \\
\text { tions, tachycardia, } \\
\text { xerostomia }\end{array}$ & $\begin{array}{l}\text { Elevated serum CK, aspar- } \\
\text { tate aminotransferase }\end{array}$ & 2.5 hours \\
\hline Our case & 2017 & $77 / \mathrm{F}$ & $\begin{array}{l}\text { Levodopa- } \\
\text { carbidopa- } \\
\text { entacapone }\end{array}$ & 30 & $\begin{array}{l}\text { Levodopa: } \\
3000 \mathrm{mg} \\
\text { Carbidopa: } \\
750 \mathrm{mg} \\
\text { Entacapone: } \\
6000 \mathrm{mg}\end{array}$ & $\begin{array}{l}\text { Altered mentality, xan } \\
\text { thoderma, yellowish } \\
\text { sclera, reddish urine }\end{array}$ & -None & 30 minutes $\sim 1$ hour \\
\hline
\end{tabular}

CK, creatinine kinase; LDH, lactate dehydrogenase.

direct bilirubin: $0.3 \mathrm{mg} / \mathrm{dL}$; aspartate aminotransferase: $46 \mathrm{u} / \mathrm{L}$; alanine aminotransferase: $3 \mathrm{u} / \mathrm{L})$, creatinine kinase $(161 \mathrm{U} / \mathrm{L})$, lactate dehydrogenase (330 U/L), and renal function tests (urea: $18.4 \mathrm{mg} / \mathrm{dL}$; creatinine: $0.78 \mathrm{~g} / \mathrm{dL}$; urine neutrophil gelatinase-associated lipocalin (NGAL): $85 \mathrm{ng} / \mathrm{mL}$ ) were within normal range. The results of urine toxicology screening were negative for benzodiazepine, tricyclic antidepressant, and barbiturate. Urine analysis showed no hematuria or pyuria, but her urine color was dark yellow to reddish (figure 1C). We performed brain computed tomography (CT), and an abdominal CT for evaluating the liver and kidney; however, there was no abnormal finding.

After initial resuscitation, her son brought along her remaining drug, which turned out to be a dose for the treatment of PD (single tablet: levodopa $100 \mathrm{mg}+$ carbidopa $25 \mathrm{mg}+$ entacapone $200 \mathrm{mg}$ ). After mental recovery, she confessed that she had intentionally taken an overdose of the drug for suicide. Thus, we diagnosed a levodopacarbidopa-entacapone overdose (levodopa: $3000 \mathrm{mg}$; carbidopa: $750 \mathrm{mg}$; entacapone: $6000 \mathrm{mg}$ ). We can exclude effect of the rhabdomyolysis because creatinine kinase and lactate dehydrogenase were normal. She was admitted to the intensive care unit for further management. On hospital day (HD)-3, she was extubated and recovered a normal skin, sclera, and urine color. On HD-10, she was discharged to a rehabilitation center for supportive care and rehabilitation. In order to exclude the effects of chronic levodopa-carbidopa-entacapone use on skin color, the patient was followed up once a month for 6 months and was free from any adverse events for a total follow-up period.

\section{DISCUSSION}

Levodopa-carbidopa-entacapone is a single combination tablet consisting of levodopa (aromatic amino acid), carbidopa (dopa-decarboxylase inhibitor), and entacapone (catechol-O-methyltransferase (COMT) inhibitor). (1) Until now, an overdose of levodopa alone (3) or that of levodopa-carbidopa (4-6) has been reported (table 1). Based on previous reports, (3-6) the symptoms of altered mental status and hypotension in our patient may be related to levodopa since only levodopa could cross the blood-brain barrier freely, unlike carbidopa and entacapone. However, there was no report concerning the overdose of levodopa-carbidopa-entacapone. Especial- ly, complications related to the overdose of entacapone have not been revealed, although its adverse reactions have been investigated. Common adverse reactions of the recommended dose of entacapone are dyskinesia and urine discoloration. Among these, urine discoloration was observed in our patient. This discoloration is due to the water-soluble metabolite of the entacapone (glucuronide conjugates). $(2,7)$ However, the cause of the change in skin color (xanthoderma) is unclear because it has not been reported as an adverse reaction of levodopa, carbidopa, and entacopone in animal studies and post-marketing surveillance. We hypothesized three potential etiological mechanisms related to skin color change. The first hypothesis was that hyperbilirubinemia, due to the hepatic impairment, may have resulted in jaundice and icteric sclera, and the subsequent yellowish discoloration of the skin and sclera. The second hypothesis was that the stimulation of melanin production due to levodopa may have resulted in the change of the color of the skin. (8) The color of melanin is blue, dark blue, and black. (9) The third hypothesis was that high levels of the conjugated entacapone caused an accumulation of glucuronide conjugates in whole body tissues. Plasma entacapone 
level is dose-dependent; thus by ingesting an excess of the entacapone, the glucuronide conjugates of the entacapone in the hepatocyte and the small intestine might increase. Although $90 \%$ of the glucuronide conjugate in the small intestine is excreted via feces, $10 \%$ remains in circulation. $(2,8)$ As seen in discolorated urine, the color of the glucuronide conjugate is dark yellow to reddish. In our patient's case, the skin and sclera color were yellowish, and liver function test including bilirubin was normal; thus, the third hypothesis provided a more likely explanation.
The differential diagnosis between xanthoderma with yellowish sclera related to the levodopa-carbidopa-entacapone overdose and jaundice with icteric sclera related to the hepatic impairment was important because the optimal treatment could be different. In the treatment of levodopacarbidopa-entacapone overdose, hemodialysis is unlikely to be beneficial due to the high protein binding of the COMT inhibitors. Patients are therefore started gradually on inotropic agents, since COMT inhibitors may interfere with the metabolism of agents such as dopamine and nor- epinephrine, thereby causing a prolonged response. (2)

Our case underscores the importance of the knowledge for new adverse reactions, related to levodopa-carbidopa-entacapone overdose. For optimal management, emergency physicians should keep in mind that an overdose of levodopa-carbidopaentacapone in PD patients may be accompanied by altered mentality, xanthoderma and yellowish sclera.

\section{REFERENCES}

1. Solla P, Cannas A, Marrosu F, Marrosu MG. Therapeutic interventions and adjustments in the management of Parkinson's disease: role of combined carbidopa/levodopa/entacapone (Stalevo). Neuropsychiatr Dis Treat 2010;6:483-90.

2. Food and Drug Administration. STALEVO. http://www.accessdata.fda.gov/ drugsatfda

3. docs/label/2003/21485_stalevo_lbl.pdf. Accessed January 3, 2017.

4. Hoehn MM, Rutledge CO. Acute overdose with levodopa. Clinical and biochemical consequences. Neurology 1975;25:792-4.

5. Sporer KA. Carbidopa-levodopa overdose. Am J Emerg Med 1991;9:47-8.

6. Stuerenburg HJ, Schoser BG. Acute overdosage and intoxication with carbidopa/levodopa can be detected in the subacute stage by measurement of 3-o-methyldopa. J Neurol Neurosurg Psychiatry 1999;67:122-3.

7. Delmas G, Rothmann C, Flesch F. Acute overdose with controlled-release levodopa-carbidopa. Clin Toxicol (Phila) 2008;46:274-7.

8. Najib J. Entacapone: a catechol-O-methyltransferase inhibitor for the adjunctive treatment of Parkinson's disease. Clin Ther 2001;23:802-32.

9. Huang P, Yang XD, Chen SD, Xiao Q. The association between Parkinson's disease and melanoma: a systematic review and metaanalysis. Transl Neurodegener 2015;4:21.

10. Stanley RJ, Stoecker WV, Moss RH. A relative color approach to color discrimination for malignant melanoma detection in dermoscopy images. Skin Res Technol 2007;13:62-72. 